\title{
Financing Risk Management of Small and Medium-sized Technological Enterprises in China
}

\author{
Jianghai QI \\ School of Economics and Management \\ Northwest University \\ Xi'an 710127, China \\ e-mail: qijianghai@ stumail.nwu.edu.cn
}

\author{
Jinmian HAN \\ School of Economics and Management \\ Northwest University \\ Xi'an 710127, China \\ e-mail: jinmianh@nwu.edu.cn
}

\begin{abstract}
Small and medium-sized enterprises are the important components of high-tech industry and the most powerful promoters. It is the backbone of improving the level of social science and technology and the pioneer of developing the knowledge economy in China. Because of the high innovation, high growth, high input, high risk and high yield of science and technology private small and medium-sized enterprises, the financing difficulty is bigger and the shortage of funds is more serious than the average small and medium-sized enterprises. Based on the analysis of domestic and foreign related research literature, this paper uses the general process of risk management of science and technology to identify and measure the risk of financing process. Finally, it puts forward the financing risk of small and medium-sized enterprises in China Management policy recommendations.
\end{abstract}

Keywords-risk management; small and medium-sized enterprises; financing

\section{INTRODUCTION}

Science and technology is a small and medium-sized enterprises is the flexibility of small and medium-sized enterprises and the development of science and technology innovation and the combination of the product, that is engaged in research, development, production and management of a certain technical content and technological innovation products enterprises in improving people's living standards, Employment and promote scientific and technological progress has played an indispensable role. The financing difficulties of small and medium-sized enterprises in the development process have not been effectively solved. In the process of development, the problem of lack of funds is often helpless and the risks brought by financing have not been effectively controlled. Financing difficulties and the risks brought by financing so that science and technology SMEs cannot really industrialization of high-tech achievements, enterprises are difficult to bigger and stronger, the economic development potential is not fully exploited. In view of this, science and technology SMEs how to change the status of their own financing difficult, how to identify and prevent financing risks is worthy of study.

For the research on the financing theory of small and medium-sized enterprises of science and technology, the financing theory began in the 1950s, and David Durant proposed three types of capital structure theory: net income theory, net income theory and traditional theory; Meyer and Miller ${ }^{2}$ put forward the MM theory, indicating that the enterprise value and financing has nothing to do; Meyers ${ }^{3}$ put forward the financing order theory, that is, the principle of pecking order, that the internal financing is better than debt financing, debt financing is better than Equity financing; Bernard Black \& Ronald J.Gilson ${ }^{4}$ that, for small and medium-sized enterprises with their own characteristics, the most suitable financing for venture capital. For the research on financing risk management of small and medium-sized enterprises of science and technology, Cheng Zhongming and Xia Yingui ${ }^{5}$ From the perspective of financing risk, this paper analyzes the direct financing risk and indirect financing risk of small and medium-sized enterprises, and puts forward the corresponding preventive measures. Sun Yongqin ${ }^{6}$ combines science and technology Enterprise characteristics, put forward the financial risk early warning system model of small and medium-sized enterprises. $\mathrm{Li} \mathrm{Zhahai}^{7} \mathrm{On}$ the basis of describing the types and characteristics of financial risks of small and medium-sized enterprises, this paper puts forward the macro and micro control strategies to deal with financial risks. Guo Wenwei ${ }^{8}$ found that the scale of small and medium-sized enterprises, the experience and the entrepreneur the level of regional economic development has a direct impact on the size of its financing risk. Fang Xianming ${ }^{9}$ puts forward the pre-control strategy of financing risk of small and medium-sized enterprises from the perspective of risk prevention, risk diversification, risk transfer and risk compensation.

Through the combing of the literature, we find that, with the increasingly important position of the economic market of small and medium-sized enterprises, the relevant experts and scholars at home and abroad have made great efforts to study the small and medium-sized enterprises, especially around the financing difficulties of small and medium-sized enterprises as the core, published a series of research results. However, the research on the financing of small and medium-sized enterprises is still relatively small. Therefore, this paper takes the small and medium-sized enterprises of science and technology in China as the research object, and according to the characteristics of China's science and technology small and medium-sized enterprises, combined with the enterprise life cycle theory, Science and technology enterprises in various periods of financing needs and the 
financing risks facing the analysis and identification, and then the SME financing risk measurement, and finally put forward the SME financing risk management measures and related recommendations in order to maximize the solution of China's science and technology Difficulties in Corporate Finance.

\section{FINANCING MODE AND RISK IDENTIFICATION OF SMALL AND MEDIUM-SIZED TECHNOLOGICAL ENTERPRISES}

According to the theory of enterprise life cycle, this paper divides science and technology into small and medium-sized enterprises: seed period, start-up period, growth period, expansion period and maturity stage. At all stages of the enterprise's life cycle, technology-based small and medium-sized enterprises have shown different financing needs. Therefore, in order to study the financing risk of small and medium-sized enterprises of science and technology, this paper needs to analyze the financing needs of the various stages of the SME life cycle and carry out risk identification.

Seed stage refers to the initial stage of the start-up of small and medium-sized enterprises of science and technology. This stage is mainly engaged in technology research and development and innovation. At this stage, the enterprise is mainly engaged in the creative intellectual labor of scientific and technical personnel, and its financing demand is not very high. Enterprise technology risk, high uncertainty, difficult to obtain financial institutions investment, the funds mainly from its own funds; start-up refers to small and medium-sized science and technology enterprises in the new technology research and development success, the new technology, new project results to the industrialization of change The financing strategy is mainly concentrated in the internal financing and venture capital, while enterprises can also go to the national policy banks to carry out certain secured credit financing; growth period is the science and technology Small and medium-sized enterprises in the stage of rapid development, small and medium-sized enterprises can take full advantage of venture capital and bank credit guarantee loans, high credibility, good market prospects from the supplier to obtain commercial credit financing; small and medium-sized enterprises to enter the expansion period The excess profits, financing needs are still large, you can More mature bank loans, the use of commercial credit and discounted bills to finance; maturity is the last stage of SME financial growth cycle, operating conditions and financial status is good, with a stable market share in the choice of financing channels In the initiative, the financing strategy is no longer concerned about how to integrate funds, but how to achieve capital structure optimization, through the issuance of shares and corporate bonds, or from bank loans to obtain funds, by optimizing the capital structure, enabling small and medium-sized enterprises to achieve late Financing and the withdrawal of venture capital, science and technology for the second venture and smooth transition to lay a solid foundation.

\section{A. Debt Financing and Risk Identification}

Small and medium-sized enterprises choose less financing methods, mainly bank loans, commercial credit and financial leasing. For the above reasons, this paper will be mainly on bank loans, commercial credit and financial leasing risk identification.

The risk of bank loan financing is mainly manifested in the fact that small and medium-sized enterprises of science and technology can not lend money from the bank to the required funds, or when the bank loans are used, the interest rate, the exchange rate and the relevant financing conditions are changed and the financing benefits cannot be repaid. The risk of commercial credit financing is mainly for the small and medium-sized enterprises of science and technology cannot purchase goods from the upstream enterprises or cannot obtain advance payment from the downstream enterprises, and the use of commercial credit financing cannot be within the agreed period of time payment Credit risk, or in accordance with the creditor's credit policy payment opportunity cost risk; science and technology SMEs use finance leasing is also facing many risks, mainly for the lack of financing, credit risk, and the implementation of financial leasing after the technical risks, Risk and interest rate risk.

\section{B. Equity Financing and Risk Identification}

Technology-based SME equity financing generally has entrepreneurial investment, retained earnings, venture capital, the issue of shares, etc., but the entrepreneurial investment and retained earnings are endogenous financing, no additional external financing costs, and thus does not constitute a financing risk Venture capitalists Covering a wide range of funds, not only individual investors, but also corporate and institutional investors, and the use of venture capital to raise funds is also large; the same, the use of stock financing is also very wide, investors not only include the majority Investors, including corporate and institutional investors. The use of venture capital and the issuance of equity financing there are external financing costs, it is necessary to risk investment risk and stock financing risk identification.

\section{Financing Structure and Risk Identification}

Financing structure risk includes two aspects, namely, capital structure risk and debt maturity structure risk. The risk of capital structure refers to the possibility that the equity capital and the debt capital structure are unreasonable to the loss caused by the enterprise. The term of the debt structure refers to the risk that the ratio of the short-term debt of the enterprise is unreasonable so that the enterprise cannot fall into the financial distress.

\section{FINANCING RISK ASSESSMENT OF SMALL AND MEDIUM-SIZED TECHNOLOGICAL ENTERPRISES}

The financing risk of the enterprise can be evaluated from different angles. Most of the existing mainstream methods are evaluated from the risk of debt financing, equity financing risk and financing structure. However, the financing source of science and technology is not single 
Debt financing or equity financing, but a combination of debt financing and equity financing. After analysis, it is found that the factors that bring the financing risk to the enterprise are nothing more than the financing cost and the financing income. Therefore, this paper intends to evaluate the financing risk of the small and medium-sized enterprises from the angle of cost analysis and income.

Capital cost rate = capital occupation fee / (total fund raising - fund raising fee)

Integrated capital cost ratio: $k_{w}=\sum_{j-1}^{n} k_{j} W_{j}$, $k_{j}$ represents $\mathrm{j}$ kind of financing cost rate, $W_{j}$ represents the proportion of the first $\mathrm{j}$ financing is the total financing, $\sum_{j-1}^{n} W_{j}=1$.

Non - liability enterprise Equity capital expected return rate: $P_{u}=\bar{R}(1-T) / S, \bar{R}$ represents Income average, $\mathrm{S}$ represents the difference between the total amount of funds raised by the enterprise and the fund raising fee, $\mathrm{T}$ represents Income tax rate.

\section{FinANCing Risk MANAGEMENT OF SMALL AND MEDIUM-SIZED TECHNOLOGICAL ENTERPRISES}

After the risk identification of the small and medium-sized enterprises of science and technology, this paper mainly analyzes the risk management measures of the small and medium-sized enterprises from the risk-taking themselves and the external risk management of the government and other institutions.

\section{A. Financing Risk Management Measures of Small and Medium-sized Technological Enterprises}

For the prevention and control of financing risk, the risk management personnel in the financing risk identification and assessment on the basis of accurate grasp of the financing process of uncertainty, for the existence of corporate financing risk to avoid, transfer, decentralization, control and other measures to the lowest The cost of risk factors or reduce the risk of risk factors, so as to obtain the greatest security. The way to prevent and control the financing risks of small and medium-sized enterprises of science and technology is as follows: First, the financing risk avoidance: refers to the possibility of estimating the potential risk of a financing scheme, and the adverse consequences are serious, and no other alternatives or There are no other strategies to reduce, so take the initiative to give up the financing program, so as to avoid the possible loss of financing risks; Second, the transfer of financing risk: insurance, security, joint ventures, venture capital and other means, small and medium-sized enterprises can use financing Leasing, joint venture, venture capital and other ways to effectively transfer the financing risk; Third, the financing risk diversification: refers to the small and medium-sized enterprises in the financing of financing using a variety of ways to build a comprehensive, multi-level financing channels, the maximum dispersion Different types of financing risks, or small and medium-sized enterprises of science and technology through diversification, the funds invested in a number of industries or a variety of product development, in order to spread the market risk, which indirectly decentralize the financing risk, the financing income Of the uncertainty to a minimum; Fourth, financing risk control refers to the enterprise to take Measures to reduce the risk of the occurrence of financing risk, or to reduce the degree of loss after the risk of financing, financing risk control is a positive risk control means; 5 , financing risk retention is the enterprise in the identification and measurement of financing risk on the basis of , To compare the various possible financing risk management approach, weigh the pros and cons, which will set aside the risk of financing within the enterprise; or that the enterprise managers because of subjective or objective reasons, the existence of financing risks and serious lack of understanding, cannot Risk processing, and ultimately by the enterprise itself to bear the risk of financing losses.

\section{B. External Risk Management Measures}

The development of small and medium-sized enterprises of science and technology depends on the effective prevention and control of financing risks. However, it is necessary to have a smooth financing channel to prevent and control the financing risks. This requires the government and other relevant departments to create a relaxed financing environment for small and medium-sized enterprises, But also based on the small scale, the strength is weak, the risk is high, the system is imperfect, the financing demand is big and so on. The science and technology type small and medium-sized enterprises alone relies on the relaxed financing environment to prevent and control the financing risk, but also strengthens the self- , Through internal and external to effectively prevent and control financing risks. The following are effective measures to effectively prevent and control the financing risks of small and medium-sized enterprises.

First: improve the relevant laws and regulations of SME financing; Second, the establishment and improvement of financial services in favor of small and medium-sized financial services system, government and other relevant departments must be through the establishment of small and medium-sized enterprises to provide financing services for small and medium-sized banks and improve the functions of existing commercial banks in two ways Thirdly, perfect the credit guarantee system which is beneficial to the financing of small and medium-sized enterprises of science and technology, establish the credit evaluation system of small and medium-sized enterprises of science and technology, innovate the incentive mechanism of credit guarantee system, and implement the mutual guarantee mode of guaranteeing the guarantee system of small and medium-sized enterprises in science and technology. ; Fifth, the establishment of multi-level risk compensation mechanism and risk dispersion mechanism to establish and improve the financing of small and medium-sized enterprises is conducive to financing the capital market, promote the development of the GEM market actively develop the bond market, and strive to develop OTC market. 


\section{REFERENCES}

[1] W. W. Rostow.The Stages of Financial Strucyure.Cambridge University Press.Cambrige. Mass.1960.

[2] Modigliani F.MillerM.The Cost of Capital.Corporate Finance and the Theory of Investment [J].American Economic Review,1958(48):261-297.

[3] Myers.S C.The Captial Structure Puzzle [J].The Journal of finance, 1984(9):575-592.

[4] Bernard S.Black,Ronald J.Gilson. Venture Captial and the Structure Of Captial Markets Banks versus stock markets [J].Financial Economics, 1998(47):243-227.

[5] Cheng Zhongming, Xia Yingui Discussion on Financing Risk of
Small and Medium-sized Enterprises and Its Prevention [J].

[6] SUN Yong-qin, Construction of Financial Risk Early Warning System for Small and Medium-sized Technological Enterprises [J]. China's Collective Economy.

[7] Li Zhahai, the financial risk control strategy of small and medium-sized enterprises under the new situation [J]. Guizhou Rural Finance.

[8] Guo Wenwei, Enterprise Characteristics, Financing Mode and Credit Risk of Small and Medium-sized Technological Enterprises [J]. Soft Science.

[9] FANG Xian-ming, Financing Risk of Science and Technology Enterprises: Source, Evaluation and Control [J]. Science and Technology Management Research. 